\title{
DAYS OF RAIN
}

\section{Francezca Kwe}

University of the Philippines Diliman

kitkwe@gmail.com

\section{About the Author}

Francezca Kwe teaches creative writing full-time at the University of the Philippines Diliman. She has received the Carlos Palanca Memorial Award for Literature and the Nick Joaquin Literary Award for her work, and her fiction has been published in the literary anthologies Maximum Volume, A Hoard of Thunder: Philippine Short Stories in English Volume II, A Different Voice: Fiction by Young Filipino Writers, Philippine Speculative Fiction I, and others, and in national publications and magazines. She received her bachelor's degree in journalism from the University of Santo Tomas, Manila, and her master's degree in creative writing from the University of the Philippines 
My father, he threw me off the wooden porch of our old house in Malabon into three feet of flood when I was 12 years old. I had eaten the fried chicken we were to have for dinner, wolfing down last the fat, oily drumstick that had occupied his thoughts the last few hours of his day at the precinct down the street. Or so he said as he picked me up by the neck of my shirt and the waistband of my shorts. "Good for nothing, we don't get nothing good out of you!"

I was watching TV in the master bedroom; soon as I heard the explosion of curses in the kitchen I rolled off the bed, and scooted off to stand in front of his scowl. The plastic dome that had covered the food was helpless in his grip, the shiny empty plate unveiled. I could already feel the heat of his palm and my neck twisting sideways even as he was flinging the dome to the sink. Facing my father, I was always prepared.

As for the flood, it had been raining for two weeks straight and water was now sucking at the last step, sending rivulets into the living room, where all our furniture were piled up on the cement blocks I had stolen from underneath the neighbor's doghouse. We had moved to the second floor, where my grandmother lived, because my mother had tired of keeping the floors dry, and the radio forecast reported that another, stronger typhoon was already on its way to us.

I bet my father, in his rage, forgot it was quite a way down. I hit the water hard, with my spine scraping the cement. Water-black and foul with overflowed toilet muck, dead animals, and drowned objects - surged into my mouth and ears, my holey briefs. Live things brushed my legs. More than the pain in my back, it was disgust-the memory that I had the day before hung over the balcony and let my torpedoes drop-that made me struggle to get up.

Heavy with water, I trudged into the house, went up the stairs and plopped at the feet of my grandmother, who, looking up from her rosary, told me to wash my legs with alcohol so I wouldn't get athlete's foot from the dirty water. My mother came with a towel and rubbed me vigorously, before going down to fry dilis. My father growled, scratching his belly in my grandmother's bed. In a few minutes, he was snoring, and I, relieved at having been spared the usual interrogation on what I had learned from his newest punishment, went back to catch the cartoons before they gave way to the evening news.

Nothing satisfied my father more than administrating proper punishment to a wrongdoer-his only tenet, guiding his 15 -year career in the police, long after church-going, marital faithfulness, and giving up seats on the bus to the elderly had been abandoned. His nickname in the force was "Five-Six," which got his Indianlike swarthiness - his dark skin, bushy eyebrows, big, broken nose-down pat, as 
well as his reputation for collecting extreme interest. "Steal twenty pesos of apples and Five-Six'll collect twenty-four blows from you," his buddies in the force used to joke.

This peculiar nobility of my father's was the simple product of having been my grandfather's son. "Hepe," as the old man had been called, had been a war hero before becoming chief of police of Paco in the '50s. He had been a double agent during the war-collaborating with the Kempeitai and simultaneously supplying the guerillas with vital intelligence.

As a child, my father used to fall asleep to the story of Hepe's first-hand account of the rape of Erlinda, the Bataan lass whose mutilation and murder had sparked a guerilla furor all over Luzon. Hepe had stood beside the Japanese captain who was rubbing himself enthusiastically as he watched his men gorge themselves on the girl, already turning blue in the face by the time the 15th soldier zipped down. From time to time the captain would turn, smiling devilishly, to Hepe, as if checking for telltale signs of sympathy on his face. But my grandfather had a poker face like a concrete slab. He only allowed himself a barely audible gulp when the captain brought his katana down on Erlinda's neck. The clincher was that after witnessing this horror, my grandfather vowed to avenge Erlinda and countless other victims by increasing his resistance efforts to full force. True to form, during the Liberation of Manila, he ran through the ruined city with bullets zinging past his ears, to a bombed-out mansion in Malate where his Kempeitai superiors were hiding, and, using his hands, teeth, and a piece of corrugated iron roof, cut eight Japanese faces open. For this, and his guerilla services, he was awarded a Medal of Honor, which used to hang on our dining room wall, next to his portrait. That portrait stared at our heads while we ate, and I had hated it since I was very small; I sensed my grandfather, with his steely eyes and grim mouth, perpetually watching me, as if critical of the compatibility of the blood flowing in my veins with the rest of me.

The hammering of these virtues into my father proved successful. To him, no fate other than filling Hepe's shoes was possible. It was as difficult to restrain him from pounding the daylights out of the snatchers and drug addicts he nightly locked up as it was to stopper his bowels, which he emptied thrice a day after meals, without exception. He meted out punishment systematically and emotionlessly, as if he were merely scrubbing a charred pot-except when it came to dealing with his only child, in which case he relaxed his math and gave free rein to his tension. I felt no desire to run away from him. Instead, my fearlessness drove me to mischief, some that escaped his notice and some that didn't. 
Among the boys in the neighborhood, I was the one without fear: of taunting the rabid askal next door with a twig, prancing an arm's length from its snapping teeth as my playmates looked on in glee, filching hot monays from Norma's, our favorite bakery, when the tattooed panadero, a Waray around whom everyone was careful, turned his back. After a full day of mischief I might go home and, the rush of adventure still kicking in, smuggle my grandfather's ancient, permanently loaded revolver out into the yard and fire aimlessly at my mother's panicked hens, for which I would earn a busted lip.

My reputation was soiled as my father's was silver. For this, I became a small legend in the eyes of the kids I knew. The most awestruck among them was Socky, a daredevil asthmatic who was in reality a distant cousin.

In the beginning he was just the new kid in school; he was a year older than me but he was nevertheless my classmate because he had missed a year of school. He and his folks-from my mother's side of the family-had moved to the city from La Union to get his father treated at the Mental, the venture failing when the bills made more progress than the patient. Soon there was no more money, and they were forced to take Tito Bing home. Word got around quickly about how he had gnawed through the leather belts strapping him to bed and wandered around town, going into the school and attempting to climb the flagpole stark naked and in plain view of all the students. I was roused from a daydream by the commotion, and as the school building shook with wild laughter, people crowding the windows, I saw that Socky was shaking with even greater intensity, wheezing like a boy possessed, yet at the same time growling like a mad dog, the chair's uneven legs drumming a rapid staccato against the cement floor as he rocked.

His house was right next to the school and we always went there for lunch. As soon as the bell rang, we would jog out of school to cut off hunger with a meal of rice that smelled of cockroaches and greasy tinola. This routine would make us friends, to Socky's benefit. Before long everyone had zeroed in on the exhibitionist's son, who in all probability harbored a dormant looniness himself. That my father was the squarest cop in town saved me from ostracism, and Socky from the school bullies by virtue of being my relative. 
He had a mother who was almost a goner herself. The woman went to work as a seamstress in an RTW shop, ending her nine-hour shift by bawling nightly for hours over her soup, periodically going into the room where her husband was tied up and squirming in a day's worth of excrement, to throw things next door with a twig, prancing an arm's length from its snapping teeth as my playmates looked on in glee, filching hot monays from Norma's, our favorite bakery, when the tattooed panadero, a Waray around whom everyone was careful, turned his back. After a full day of mischief I might go home and, the rush of adventure still kicking in, smuggle my grandfather's ancient, permanently loaded revolver out into the yard and fire aimlessly at my mother's panicked hens, for which I would earn a busted lip.

My reputation was soiled as my father's was silver. For this, I became a small legend in the eyes of the kids I knew. The most awestruck among them was Socky, a daredevil asthmatic who was in reality a distant cousin.

In the beginning he was just the new kid in school; he was a year older than me but he was nevertheless my classmate because he had missed a year of school. He and his folks - from my mother's side of the family-had moved to the city from La Union to get his father treated at the Mental, the venture failing when the bills made more progress than the patient. Soon there was no more money, and they were forced to take Tito Bing home. Word got around quickly about how he had gnawed through the leather belts strapping him to bed and wandered around town, going into the school and attempting to climb the flagpole stark naked and in plain view of all the students. I was roused from a daydream by the commotion, and as the school building shook with wild laughter, people crowding the windows, I saw that Socky was shaking with even greater intensity, wheezing like a boy possessed, yet at the same time growling like a mad dog, the chair's uneven legs drumming a rapid staccato against the cement floor as he rocked.

His house was right next to the school and we always went there for lunch. As soon as the bell rang, we would jog out of school to cut off hunger with a meal of rice that smelled of cockroaches and greasy tinola. This routine would make us friends, to Socky's benefit. Before long everyone had zeroed in on the exhibitionist's son, who in all probability harbored a dormant looniness himself. That my father was the squarest cop in town saved me from ostracism, and Socky from the school bullies by virtue of being my relative. 
He had a mother who was almost a goner herself. The woman went to work as a seamstress in an RTW shop, ending her nine-hour shift by bawling nightly for hours over her soup, periodically going into the room where her husband was tied up and squirming in a day's worth of excrement, to throw things at the old man, screaming at him to shut up, when the only sound was that of her own sobbing.

My skill at evading the chaos of my own household became useful for extracting Socky from his house for cola at the corner store or a spin on our bikes. With our slingshots in hand we would go off to terrorize stray cats, and when it rained, steal canoes from where they bobbed in front of houses and row away like crazy while the owner flung stones at our heads. From him I learned to make poison beer. The process involved dunking a toad in a jar of Pale Pilsen, swishing it around until it nearly drowned, and eventually releasing it, though it would become so pissed that it could no longer crawl away for its life. According to Socky, we were drinking the strongest stuff on Earth-the beer was spiked with the toad's toxic juices, becoming an elixir that would make us invincible.

Our brotherhood was solid. Despite or maybe because of his asthma, Socky was a sport, eager to prove he could go beyond a thirteen-year-old's limits. He was surprisingly a strong swimmer, having practically been born in a lake, and we would swim in the streets where the flood reached to a grown man's temples. He was liable to get as crazy as his old man sometimes, as when, eyes wild with excitement, he challenged me to jump into the swollen river during a typhoon, something I refused outright. He went through with it, albeit in the summer.

"That boy will grow up to be an addict, if he doesn't lose his bolts first," my father would growl, sometimes even in Socky's presence. The dislike was mutual. Later in our friendship, I would learn why Tito Bing had gone off his rocker-years ago he had been pinpointed as a drug pusher by some cops eager to meet their monthly quota. He was thrown into the provincial jail, and kept there for weeks as a punching bag for cops and a convenient bunghole for inmates. When he got out he lay catatonic for weeks at the hospital, before slowly lapsing into lunacy over the years.

Halfheartedly trying to sympathize, I told Socky that probinsyano cops were all losers who jacked off while watching the inmates rub each other raw, but he looked up with a glint of adult wisdom in his eyes. "I hate every kind of cop." It turned out that my father had chosen to ignore Tita Wilma's pleas for his help in her husband's case, because he believed that Tito Bing was truly snorting crack. 
To his own father, Socky was almost tender. Tito Bing was steadily getting worse, taking to howling so much that sitting in class, we could have fancied the afternoon transformed into a bedeviled moonlit night.

But Socky decided one day that enough was enough. We skipped a late afternoon class and at his house found the old man whimpering, soiled and stinking to high heavens.

I took a kitchen knife and laboriously went to work on the leather, while Socky soothed his father, stroking his head. We had to help Tito Bing to his feet and hold him up for several minutes, waiting for his limbs to wake up. Socky put fresh clothes on him, and we brought him out to the garden, where he shuffled around in circles. The guy was nuts beyond hope, I thought, biting the thought back as I glanced at the huge grin on Socky's face. His father was calm and sitting on the ground, munching on a stick of cactus. We contentedly watched Tito Bing sample some other plants, before it dawned on us that the old man was starving.

After that, because Tita Wilma was probably tired to the marrow, they let him loose. No more major accidents followed, except whenever a storm blew he would stubbornly venture outside in the rain to the school and water the flowerbeds.

We became a trio after that, Socky's father trailing after us everywhere like a dog, licking clean the plastic wrappers of cornbits and chips we constantly satiated ourselves on. The old man particularly loved a good storm, and we would venture out into afternoons white with rain and get soaked on the embankments. A ghost of a man and two boys, whooping like devils. Sometimes, Socky would stare into the river as it heaved about our feet.

“They haven't seen the last of us," he would whisper, eyes gleaming, seeming as deranged as his old man.

The typhoons came and went in time with our growth spurts, the antics we diligently went about accomplishing, which intensified in high school. I could feel my father's scorn boiling whenever he was around me. I'd lie at my Lola's feet having my scalp scratched and hear him complain to my mother. "That son of yours is embarrassing me. Look how he goes around with that lunatic and his junkie son." 
As long as he didn't catch me red-handed, he didn't touch me. I used the reprieve to think up bolder schemes that would raise my mastery of misbehavior to higher levels. For a while, we enjoyed being runners for a small-time shabu dealer, after we got tired of pilfering from the local supermarket, puncturing tires or hanging out at sari-saris bullying small children out of the money their mothers gave to buy food. With the cool income I bought myself new basketball shoes, which I kept hidden from my father in my grandmother's antique wardrobe, underneath the bulk of her yellowed traje de boda. Socky used his money for a new set of clothes for Tito Bing - fresh underwear, collared shirts, denims and a pair of smart-looking

leather shoes. "He won't be much comfortable in them," I said as we wrestled him out of his rags into the new clothes. He howled and contorted like a pig being led to slaughter. But Socky persisted in dressing up the old man everyday, no matter how much he flailed. 'Just because he's like this doesn't mean he has to look like shit," Socky would mutter, gritting his teeth. On one particularly lazy day, we three all dressed up, intrepidly ventured into a Max's, and gorged ourselves on all the fried chicken we could force down.

But one day a horde of cops, my father at the helm, beat down the squatter's shanty where Socky and I were collecting our weekly cut. There was no time to flee; no sooner had my father set eyes on me than I was already flying across the room and smashing against a plywood wall. I staggered to my feet as he stood over me, nostrils flaring, the raid half-forgotten amid the faint sniggering of his men.

The thrashing continued at home, under my grandfather's frozen, approving glare. Such was my father's fury that he knocked out three of my teeth. He was on the verge of snapping my neck in two when my mother finally worked up the gall to step in between us. "That son of yours," my father spat out, sweating like a racehorse. "I don't know how to deal with him!"

From across the room, my grandmother's voice floated over like a song. "Beating him up's the only way you know how, anyway." She sat on a rocking chair staring at the wall. My father's fists dropped to his sides, my mother relaxed her stance, but her precious lucid moment passed and Lola drifted back to a recollection of Hepe during the '5os and a frilly red dress she once owned. My father whipped his head around, his rage dissipating but still smoldering. 
After a week I was up and hobbling, having missed several days of class but game as hell again for anything, including another beating. But Socky seemed to have lost interest; he would sit around bouncing a rubber ball against their kitchen wall in a daze while Tito Bing roamed the streets in his finery. "What the devil's gotten into you?" I asked him.

"I'm in love," he said, grinning.

The girl was a classmate of ours. She used to merely be a mass of hair blocking his view of the blackboard. But one drowsy day during my recovery, as the teacher read aloud a love scene from Florante at Laura, the girl suddenly went into violent convulsions, falling to the floor in a heap, froth spilling out of her mouth like beer fresh out of a bottle. Socky had been one of the boys who had carried the girl to the school clinic. On the way he couldn't stop looking down at her, he said, fascinated with the way her eyes were rolling up into her head. By the time they had deposited her in the care of the nurse, he was thoroughly smitten.

Pretty soon, Socky was swooning over someone as impaired as he was, for the girl turned out to be a repressed epileptic. "She's fragile as a puppy," Socky would exclaim as we trailed after the girl in the school corridors.

Her name was Emily and she wasn't particularly pretty; she had a round, broad forehead tickled by wisps of hair escaping a barrette, two enormous front teeth and eyes that had a bit of the Oriental-they made me think, curiously, of the shape of raindrops, or tears. What Socky liked best was her smooth skin, with its light down, which differed sharply from the acne-pitted cheeks of the other girls.

Socky began his pursuit almost immediately; this was, he said, an opportunity to elevate his experience above endlessly replaying the twenty-odd tapes we had swiped from the confiscated porn piles at my father's station. He began the expected barrage of flowers and love notes written painstakingly on onionskin paper, the letters guided by a ruled pad underneath. The ramrod-straight lines stood tersely on the page, the bottom half of the letters stuck to invisible lines, looking like so many deflated tires. Between the two of us, I fared better in language class-his territories were science and history-and soon, I found myself doing lip service to his love on pack after pack of cheap scented stationery while he paced around the room waiting for me to set the pen down.

No reply came to the letters but Socky's luck changed when Emily offered to be his partner for a social science project. That afternoon she biked to his house, where we were chugging down vile cocktails made out of beer, rum, and whatever happened to be in the kitchen. She balked at Tito Bing, who was sitting on the 
ground in his briefs and a striped polo shirt, but agreed to go into the house. Socky's declarations of love seeped out into the yard where I shuffled a deck of cards, to the old man's delight. After an hour, Emily ran out and flew away on her bike, and Socky came cartwheeling out of the doorway.

For a month Socky walked her to and from school, sat with her during PE, from which they were both exempted. They had gone to as far as kissing, and he was over the moon about a chance encounter between his hand and her premature, fourteen-year old breast.

Their togetherness, however, was short-lived. In a matter of days Socky was passed over for one of the juniors, who to boot, had been one of his biggest tormentors in grade school. One of those big brawny types whose scalp reeked of old money bills for sheer want of a bath. I'm sorry, Emily said in her first and last letter, I can't be with you anymore because your father is a loony. Unable to restrain himself, Socky charged at them like a bull during recess. But he caught the new boyfriend's fist squarely in the nose. After hours, I watched him pummel a blackboard until his knuckles were raw.

"Fuck them," he whimpered, "they'll pay."

It's hardly worth the effort, I told him, but my words were drowned out by the sound of wood breaking into fragments.

We were, as Socky said, to give her a little scare. "Brandish the big stick, you mean," I joked. "It's the kind of thing my father does."

"Don't compare us," Socky said, gripping my shoulders. His palms burned through my shirt. "This is our own game, remember." He shook me for emphasis. "Listen, all your life they'll force a gun down your throat and make you beg for your life. Don't do it."

He flung a rock against a sorry-looking piece of driftwood in his yard. I felt drops on my face and looked up. The sky above us was gray like the slit insides of a dead fish.

The next day, the two of us, with Tito Bing, skulked around in a side street next to school, waiting for Emily to emerge from classroom cleaning duties. The school was empty, still under the threat of rain. Pushed by the wind, leaves scuttled 
on the ground. Tito Bing busied himself by picking up grimy candy wrappers and stuffing them into his pockets.

Socky, slouched against a wall, straightened up at the sound of footsteps. We watched as Emily, absorbed in a comic book, entered the mouth of the alley. She stumbled right in, good as blind, and almost went sprawling as her legs bumped into Socky's outstretched foot. She gasped, and the comic book went fluttering down, a bright patch on the dirty ground. want?"

"Oh, it's you," she said, scowling before she could think twice. "What do you

"Just to talk," Socky said. He had his hands in his pockets; with one look he motioned for me to move behind her. I slinked as bidden, as Emily's annoyance bubbled up to her face. She swung her glance between Socky and me as if following the flight of flies.

"Where's your new boyfriend?" Socky asked, coming closer to Emily, who had picked up her comics and was dusting it against her skirt.

"It's none of your business," she said, scanning the pages for stains.

I could see Socky's jaw muscles moving in a spasm. He lunged forward to snatch her wrist; one fluid movement, like a snake. "You cheated on me," he hissed. "Isn't that my business?"

Emily's eyes were widening. "Let me go," she said. "You're crazy, let me go." Tito Bing, attracted by the shrill sound of her voice, ambled to us. He fingered the comic book in her hands. She screamed. "Get the kook away from me!"

Sneering, Socky gripped her chin, crushing her mouth into two trembling globs of pink flesh. "Who do you think you are?" he yelled, right into her face. He pressed his palm against her face and gave her a hard shove. She fell into my arms and by instinct I held them out in a cage around her. Socky was unzipping his pants.

"Man, what are you doing?" I asked, trying to contain Emily, who was squirming. "Shut up and help me," he said, "we're in this together." I pinned her facedown on the ground as Socky pulled her skirt up and yanked her underwear down. For a moment, the sight of bare flesh ground us to a halt, and we stared down at her buttocks dumbly while she screamed with all her might against the asphalt. Tito Bing, thinking it was a game, added his weight to ours, holding Emily's feet down. "Let's let her go, Socky," I said. "We'll just scare her into not telling." 
Socky was silent. Robotically, he knelt down and shoved himself into her. He lay on top of her, one hand pressing down on the back of her head. Her muffled screams seemed far away and tiny, as if somewhere between us and the wind, a kettle was whistling. A gust brought drops to my cheeks and soon the rain bore down on us, dripping off Socky's face into Emily's skirt, darkening blue into black. There must have been, among my dreams, something like this, I thought, staring at my knuckles, which were being rubbed raw into the cement as Socky rocked, the movement passing through all four of us-two boys, a girl and an old man-like water.

That was the last time I saw Socky. The next day the river swelled into a beast ramming the banks, stroked approvingly by the rain. I was lying in bed, curled up, staring at the wall and inhaling the musty smell of damp wood when my mother went into my room. "Something happened to Socky," she said, in a small voice. "They found him in the river." In a low voice, she told of how some residents had come across Tito Bing wailing on the bank in the night, drenched to the skin. He was pointing at the water, screaming whenever anyone attempted to move him. A few hours later, Socky's body was found knocking against an old boat.

I got up and fetched my grandfather's gun. I crossed the yard in the hard rain and emptied out the rounds on the sleeping chickens, the coops, the walls. I shut my eyes, and began to shout all the profanities I knew, even some I hadn't known I knew, driving my voice louder and louder until I could imagine the sound penetrating the bloody heaps of feathers, blasting the innards open with its force.

In the corner of my eye I could see my mother, hand to her mouth, hovering at the open door. She was suddenly pushed aside, and the figure of my father came barreling towards me.

His fist rammed into my jaw, and the gun fell out of my hands into a puddle. For the first time, I found myself flailing against him, striking out for all I was worth. I felt my fist slamming into his nose. Dropping to my knees, I groped in the slush for the gun, forgetting that there were no bullets left.

I felt myself being jerked up by many hands. The rain was a fine film all around, breaking on the shoulders of brown-clad men, hunched over me like beings that rose up out of the mud. My father stood rubbing his nose. The men hauled me up, through the yard, and the house, past my open-mouthed grandmother and my sobbing mother, out of the gate and into a purring jeep. I could see my mother wringing her hands as my father trudged to his car. 
News travels fast, even in a storm. A foot into the precinct, I saw a commotion along the front desks. In between the human figures, I caught a glimpse of Emily, face shiny with tears. The tension in the air turned into pure electricity when I entered, borne along by four cops, my feet trailing on the floor. My stomach felt cold and shrunken, as I was positioned in front of Emily and a group of men with tense, knotted faces, nostrils flaring. In their eyes a look wilder and darker than what I had seen in Socky's. My father came then into the room, his head down. Instead of coming forward, he kept off to the side, posture as rigid as always. In a moment of madness, I thought of wresting free from my guards, and running to him, to cower at his feet. But before I could blink I was thrust forward.

"Is this him?" one cop asked Emily.

In response she burst into a wail, and turned to burrow into a woman beside her, whose feral stare was almost leaping out of her face. "Give him over to us, boss," one of the men with her said. "We just want a shot at him."

The cops at my side melted away. A curtain of men closed around me, snarling, hungry for blood. I turned towards my father's direction and saw, beyond the descending fists, his face in a blur. I was vaguely aware of anything else but eruptions of pain all over my body-blinding, breathless, colliding into each other like boulders, a landslide of pain burying me alive. In my mouth and nostrils, the taste of metal; each breath I drew set my insides on fire. every blow.

My sight was dimming, and I could feel my body crumpling, deflating with

I heard, faintly, a voice crying, "Stop, please." I knew the voice; I could recognize it though I was teetering on the edge of the world. I felt a pair of hands pull me up, and felt my father's heartbeat against my cheek. I opened my eyes and saw, deepening outside the open door, the quiet night. 